\title{
PENGARUH LATIHAN LOMPAT TALI DAN LOMPAT KATAK TERHADAP HASIL LOMPAT JAUH GAYA JONGKOK
}

\author{
Rudi $^{1}$, Udi Sahudi ${ }^{2}$, Syaiful Mumin ${ }^{3}$ \\ Universitas Majalengka, Indonesia \\ email:alvarizi.rudi@gmail.com
}

\begin{abstract}
ABSTRAK. Tujuan dari penelitian ini adalah untuk mengetahui daya ledak otot tungkai pada nomer lompat jauh gaya jongkok. Penelitian ini menggunakan metode eksperimen karena adanya perlakuan yang sengaja ditimbulkan dalam penelitian, Subjek dalam penelitin ini adalah peserta didik sekolah menengah atas Madrasah Aliyah Fatahillah Lohbener, Indramayu. Dengan populasi 29 orang. Penelitian ini menggunakan teknik total sampling untuk menentukan sampel yang akan digunakan dalam penelitian, yang berjumlah 29 orang, antara lain laki-laki yang berjumlah 14 orang dan perempuan 15 orang. Dari hasil penghitungan statistika menggunakan program microsoft excel.Teknik pengumpulan data menggunakan tes awal dan akhir intsrumen penelitian yang digunakan adalah penilaian produk/prestasi teknik lompat jauh. teknik analisis digunakan teknik pengujian normalitas dan homogenitas serta pengujian hipotesis. Data tes awal untuk rata-rata dari pengujian latihan lompat tali dan lompat katak adalah 2,76 sedangkan untuk data tes akhir adalah 2,81. kemudian hasil dari simpangan baku nya dalam tes awal adalah 0,32 sedangkan hasil dari tes akhirnya adalah 0,32 . Sedangkan taraf signifkansi nya adalah 0,05 kemudian daftar distribusi t nya adalah 0,806 Berdasarkan hasil ini, dapat disimpulkan bahwaa ada pengaruh yang signifikan terhadap hasil lompat jauh gaya jongkok. dengan metode latihan lompat tali dan lompat katak..
\end{abstract}

Kata Kunci: Lompat Tali; Lompat Katak; Lompat Jauh Gaya Jongkok

\section{Pendahuluan}

Atletik adalah sebuah bagian olahraga yang terdiri dari beberapa jenis olahraga sekaligus dimana secara keseluruhan olahraga tersebut dapat di kelompokkan menjadi tiga cabang besar yakni: Lari, lompat, lempar, dan kemudian di dalam olahraga atletik itu ada yang namanya nomer lompat salah satunya yaitu nomer lompat jauh. Lompat jauh adalah melompat sekuatkuatnya dengan kaki terkuat untuk mendapatkan hasil yang maksimal di dalamnya. Menurut Hendrayana, (2013), lompat jauh adalah "Membangun awalan secepat-cepatnya dan melakukan tolakan yang sekuat-kuatnya ke arah depan-atas dengan satu kaki untuk meraih ketinggian yang optimal saat melayang sehingga menghasilkan jarak lompatan yang sejauh-jauhnya". Dari uraian tersebut dapat kita tarik kesimpulanya bahwa lompat jauh adalah melompat kedepan dengan kaki terkuat, kemudian lompat jauh membutuhkan kekuatan power di kaki nya atau daya ledak otot tungkai nya untuk menolak kedepan supaya menghasilkan tolakan yang bagus dan maksimal.

Dalam pendidikan jasmani ada salah satu bidang yang di cantumkan dalam silabus yang di terapkan di Madrasah Aliyah salah satunya adalah olahraga lompat jauh. Lompat jauh adalah cabang olahraga perorangan atau individu yang didalamnya tidak mengenal unsur kerjasama 
dan di butuhkan teknik individual yang baik untuk mendapatkan hasil lompatan yang jauh. Dan di dalam lompat jauh itu ada teknik yang harus di kuasai yaitu awalan, tolakan, melayang, mendarat. Dari pembahasan di atas dapat kita simpulkan bahwa ada empat gerakan lompat jauh gaya jongkok antara lain awalan, tumpuan, melayang di udara, mendarat. Keempat gerakan tersebut yang akan menghasilkan gerakan lompat jauh yang maksimal dalam atletik khususnya dalam cabang olaharaga lompat jauh gaya jongkok.

Berdasarkan hasil observasi lompat jauh yang di kumpulkan sebelumnya di Madrasah Aliyah (MA) Fatahillah, Lohbener Indramayu ditemukan masih adanya peserta didik yang kurang kuat dalam melakukan tolakan sehingga hasilnya kurang maksimal.

Dari hasil observasi di atas dapat kita simpulkan bahwa peserta yang nilainya kurang maksimal dalam lompat jauh dapat di kembangkan dengan latihan lompat tali dan lompat katak untuk mendapatkan kekuatan tolakan dan hasil yang lebih baik dalam lompat jauh gaya jongkok tersebut. Lompat tali adalah permainan yang menyerupai tali yang disusun dari karet gelang, ini merupakan permainan yang terbilang sangat populer sekitar tahun 70-an sampai 80-an, menjadi favorit saat "keluar main" di sekolah dan di rumah. Sederhana tapi bermanfaat, bisa dijadikan sarana bermain sekaligus olahraga. Tali yang digunakan terbuat dari jalinan karet gelang yang banyak terdapat di sekitar kita. Cara bermainnya bisa dilakukan perorangan atau kelompok, Menurut Shandy, (2013) Dalam Zulkarnain, Dkk. (2016) "Menurut bahasa lompat tali (Skipping) berasal dari bahasa inggris yaitu "Skipp" yang artinya lompatan atau loncatan melewati tali”. Loncatan itu merupakan suatu bagian yang penting dalam dunia gerak manusia. Anak-anak pada umumnya suka meloncat-loncat untuk menyatakan kegembiraannya dan kesukaannya untuk bergerak. Pada umumnya pula manusia itu mempunyai sifat ingin mempertinggi kecakapan dan ketangkasan, yang lama kelamaan berubah menjadi perlombaan melawan sesamanya.

Kemudian latihan kedua itu dengan latihan lompat katak yaitu dimulai dengan berdiri pada dua kaki selebar bahu, kemudian melakukan lompatan kedepan tanpa menggunakan penghalang tetapi lompatan ini dilakukan dengan sejauh-jauhnya. Gerakan lompat katak dilakukan dengan kaki ditekuk dan mendarat pada dua kaki, badan harus tetap pada garis lurus. penulis tertarik melakukan penelitian dalam upaya meningkatkan hasil lompat jauh gaya jongkok dengan judul: "Pengaruh latihan lompat tali dan lompat katak terhadap hasil lompat jauh gaya jongkok". 


\section{Metode Penelitian}

Metode yang digunakan pada penelitian ini adalah metode eksperimen, yaitu suatu metode yang dilakukan dengan cara memberikan perlakuan terhadap subjek penelitian. Metode Menurut Arikunto (Maulana, 2014). menjelaskan bahwa "Metode penelitian adalah cara yang digunakan oleh peneliti dalam mengumpulkan data penelitiannya”. Kemudian menurut Sugiyono, (2017), adalah "Metode penelitian pada dasarnya merupakan cara ilmiah untuk mendapatkan data dengan tujuan dan kegunaan tertentu".

Pada penelitian ini, rancangan yang peneliti gunakan one grup Pre test-Post tes Design. Dalam rancangan ini digunakan satu kelompok subjek. Setelah selesai penarikan sejumlah sample, maka terhadap sample diberikan tes awal lompat tali dan lompat katak tiap orang melakukan latihan lompat tali dan lompat katak selama 1-2 menit. kemudian peserta didik melakukan tes akhir yaitu lompat jauh gaya jongkok.

Populasi dan sample yang digunakan dalam penelitian ini adalah seluruh kelas 12 yang berjumlah 29 orang. Tes yang digunakan adalah hasil lompat jauh gaya jongkok yang dilakukan dua kali saat tes awal dan tes akhir.

\section{Hasil dan Pembahasan}

Dari hasil pengolahan data diperoleh nilai rata-rata dan nilai simpangan baku dari tiap kelompok sample, hasil tersebut adalah sebagai berikut:

Tabel 1

Hasil Penghitungan Nilai Rata-Rata Dan Simpangan Baku Tes Awal

\begin{tabular}{|c|c|c|}
\hline Perlakuan & Rata-Rata & $\begin{array}{c}\text { Simpangan } \\
\text { Baku }\end{array}$ \\
\hline Latihan Lompat Tali dan Latihan Lompat Katak & 2,76 & 0,32 \\
\hline
\end{tabular}

Kesimpulannya adalah bahwa nilai rata-rata dari tes awal latihan lompat tali dan lompat katak adalah 2,76 dan nilai dari simpangan bakunya 0,32.

Hasil Penghitungan Nilai Rata-Rata Dan Simpangan Baku Tes Akhir

\begin{tabular}{|c|c|c|}
\hline Perlakuan & Rata-Rata & $\begin{array}{c}\text { Simpangan } \\
\text { Baku }\end{array}$ \\
\hline Latihan Lompat Tali dan Latihan Lompat Katak & 2,81 & 0,32 \\
\hline
\end{tabular}

Kesimpulannya adalah bahwa nilai rata-rata tes akhir latihan lompat tali dan lompat katak adalah 2,81dan nilai dari simpangan bakunya adalah 0,32. 


\section{Uji Normalitas}

Dalam uji normalitas penulis menggunakan uji lilifors, dengan kriteria terima $\mathrm{Ho}<\mathrm{L}_{\text {Tabel }}$ Berikut adalah hasil uji normalitas distribusi data:

Hasil Uji Normalitas Lilifors Tes Awal

\begin{tabular}{|c|c|c|c|}
\hline Perlakuan & Lo $_{\text {o1-Hitung) }}$ & LTabel & Kesimpulan \\
\hline $\begin{array}{c}\text { Latihan Lompat Tali dan Latihan Lompat } \\
\text { Katak }\end{array}$ & 0,96 & 0,156 & Normal \\
\hline
\end{tabular}

Hasil Uji Normalitas Lilifors Tes Akhir

\begin{tabular}{|c|c|c|c|}
\hline Perlakuan & Lo(1-Hitung) & LTabel & Kesimpulan \\
\hline $\begin{array}{c}\text { Latihan Lompat Tali dan Latihan Lompat } \\
\text { Katak }\end{array}$ & 0,96 & 0,156 & Normal \\
\hline
\end{tabular}

Berdasarkan hasil pengujian normalitas untuk tes awal diperoleh nilai $\mathrm{L}_{\mathrm{O}} 0,96$ sedangkan $\mathrm{L}_{\text {tabel }}$ dengan tingkat kepercayaan 0,05 dengan jumlah sample $(\mathrm{n})=29$ diperoleh nilai 0,156 pada daftar tabel untuk lilifors.

Dengan demikian dari hasil pengujian dan analisis data yang dilkukan, maka didapat hasil bahwa kelompok sample pada tes awal dan tes akhir mempunyai $\mathrm{L}_{0}$ yang lebih kecil dari $\mathrm{L}_{\text {Tabel }}$ maka kedua kelompok tersebut berdistribusi normal.

\section{Uji Homogenitas}

Setelah nilai rata-rata dan simpangaan baku diketahui, maka langkah selanjutnya adalah melakukan uji homogenitas dari data tes tersebut. pertama dalam uji homogenitas adalah menghitung variansi tes awal, tes akhir sebagai berikut hasil penghitungannya:

\section{Hasil Penghitungan Variansi Tes Awal dan Akhir}

\begin{tabular}{|c|c|c|}
\hline Perlakuan & Tes Awal $\left(\mathbf{S}^{\mathbf{2}}\right)$ & $\begin{array}{c}\text { Tes } \\
\text { Akhir( }\end{array}$ \\
\hline $\begin{array}{c}\text { Latihan Lompat } \\
\text { Tali dan Latihan Lompat } \\
\text { Katak }\end{array}$ & 0,108 & 0,107 \\
\hline
\end{tabular}

Selanjutnya bandingkan variansi terbesar dan terkecil diantara latihan dari tes awal, tes akhir. Kemudian hasilnya dibandingkan dengan nilai dari tabel distribusi F. 
Hasil Penghitungan Uji Homogenitas

\begin{tabular}{|l|c|c|l|}
\hline \multicolumn{1}{|c|}{ Perlakuan } & FHitung & FTabel & \multicolumn{1}{|c|}{ Kesimpulan } \\
\hline Tes Awal & 1,01 & 2,03 & Homogen \\
\hline Tes Akhir & 1,01 & 2,03 & Homogen \\
\hline
\end{tabular}

Keriteria pengujian homogenitas tersebut adalah terima hpotesis Ho jika, F (1-a)(n-1) $<\mathrm{F}<\mathrm{F}^{1 / 2_{\mathrm{a}}}(\mathrm{n} 1-1)$ dan tolak Ho jika $\mathrm{F}<\mathrm{F}<\mathrm{F}^{1 / 2_{\mathrm{a}}}(\mathrm{V} 1)$. Atas dasar hasil pengujian variansi di atas, diketahui bahwa hasil F-hitung tes awal = 1,01 lebih kecil dari F-tabel 2,03 pada $\mathrm{dk}=(29,29)$ dengan taraf nyata ${ }^{\mathrm{a}}=0,05$. kesimpulannya dari hasil pengujian kesamaan dua variansi adalah satu kelompok data tes awal homogen. hasil F-hitung tes akhir $=1,01$ lebih kecil dari F-tabel 2,03 pada $\mathrm{dk}=(29,29)$ dengan taraf nyata ${ }^{\mathrm{a}}=0,05$. kesimpulannya dari hasil pengujian kesamaan dua variansi adalah satu kelompok data tes akhir homogen. Jadi kesimpulan dari hasil pengujian homogenitas tes awal,tes akhir dan adalah bahwa kelompok sample tersebut berasal dari populasi yang homogen

\section{Kesimpulan}

Hasil Penelitian yang diperoleh dari latihan lompat tali dan lompat katak adalah Data tes awal untuk rata-rata dari pengujian latihan lompat tali dan lompat katak yaitu 2,76 sedangkan untuk data tes akhir adalah 2,81 . kemudian hasil dari simpangan baku nya dalam tes awal adalah 0,32 sedangkan hasil dari tes akhirnya ialah 0,32. Sedangkan taraf signifkansi nya adalah 0,05 kemudian daftar distribusi $\mathrm{t}$ nya adalah 0,806. Berdasarkan hasil ini, dapat disimpulkan bahwaa ada pengaruh yang signifikan terhadap hasil lompat jauh gaya jongkok. dengan metode latihan lompat tali dan lompat katak.

\section{Daftar Pustaka}

Arikunto, S. (2014). Prosedur Penelitian, Suatu Pendekatan Praktik. Jakarta: Rineka Cipta.

Badriah, D. L. (2013). Fisiologi Olahraga.Bandung: Multazam

Badriah, D. L. (2012). Metodologi Penelitian, Ilmu-Ilmu Kesehatan. Bandung: Multazam

Sidik, D. Z. (2011). Mengajar Melatih Atletik. Bandung: Pt. Remaja Rosdakarya Offset.

Sari, D. V. (2015). Pengaruh Latihan Loncat Katak Terhadap Daya Ledak Otot Tungkai Pada Pemain Futsal. Surakarta: Jurusan Diploma IV Fisioterapi Fakultas Ilmu Kesehatan Universitas Muhamadiyah Surakarta.

Emral. (2017). Pengantar teori dan metodologi pelatihan fisik. Depok: Kencana. Florentana. 2015. Pengaruh Pelatihan Lompat Katak Terhadap Kekuatan dan Daya Ledak Otot Tungkai. Malang: Jurnal IKOR Universitas Pendidikan Ganesha Jurusan Ilmu Keolahragaan.

Wiarto, G. (2013). Atletik. Yogyakarta: Graha Ilmu

Hendrayana, Y, Rahmat, A. (2013). Bermain Atletik. Bandung: Prodi PJKR Jurusan Pendidikan Olahraga Dan Kesehatan. Universitas Pendidikan Indonesia.

Harsono. (2015). Kepelatihan Olahraga. Bandung: PT Remaja Rosdakarya

Mardianto, M. I. (2013). Peningkatan Hasil Belajar Lompat Jauh Melalui Pendekatan Pembelajaran Bermain Loncat Katak. Semarang: Jurusan Pendidikan Jasmani Kesehatan Dan Rekreasi, Fakultas Ilmu Keolahragaan Universitas Negri Semarang. 
Putra, R. (2017). Pengaruh Latihan Jump To Box Dan Latihan Skipping Terhadap Tinggi Lompatan Siswa. Lampung: Fakultas Keguruan dan Ilmu Pendidikan Universitas Lampung.

Sugiyono. (2017). Metode Penelitian Kuantitatif Dan Kualitatif Dan R\&D. Bandung: Alfabeta.. 